\title{
QUALITATIVE INDICATORS OF BANK PERFORMANCE ASSESSMENT FOR THE PURPOSES OF PARTICIPATION IN THE DEPOSIT GUARANTEE SYSTEM IN UKRAINE
}

\author{
Oleh Ilnytskyi ${ }^{1}$, Natalia Ilkiv ${ }^{2}$, Khrystyna Chopko
}

\begin{abstract}
One of the directions of reforming the system of deposit insurance in the world is risk-oriented approach, which means that the degree of involvement in the system is determined by the degree of exposure of the participant's operations to risk. Correct estimation of the degree of risk of banking operations requires a well-grounded approach to the study of indicators-criteria that should be clear, understandable, and objective. The subject of research is the performance of the deposit guarantee system in Ukraine. Therefore, the present research aims to solve applied problems of establishing the content of qualitative indicators of banking operations that arise in their application for the sake of determining the degree of risk in the operations of the participant of the Deposit Guarantee Fund in the estimation of the amount of recurring charges.

Methodology. Systemic method was applied to establish the content and assign qualitative indicators of bank performance for establishing their actual content in accordance with the regulation. On this basis, using a formal logical method, definitions of legal notions were formulated with due account of the financial and economic meaning as well as the established goal of legal regulation. Formal dogmatic approach allowed to make an analysis of the regulatory and legal framework of the state, to identify functional capacity of the system of protection of the rights and interests of bank depositors, their technical and legal excellence. Also, a number of other general scientific methods of research were applied, in particular: analysis (to study systemic application of the notions), historical legal (to study the establishment, change and development of the deposit guarantee system), comparative legal (to study the legislation determining specific principles of the functioning of the deposit guarantee system of natural persons in foreign states) etc. As the result, there has been established the essence of the current qualitative indicators used in the determination of the degree of risk of banking operations in Ukraine as far as application of the means of influence for violation of banking legislation by the National Bank of Ukraine to participating banks over the reporting period, as well as administrative and economic sanctions applied for violation of legislative requirements related to the deposit guarantee system of natural persons are concerned. Also, proposals have been developed concerning the procedure of their application for the sake of increasing the opportunities for ensuring risk-oriented approach.
\end{abstract}

Key words: risk-oriented approach, written warning, fine, administrative and economic sanctions, recurring charge.

JEL Classification: E61, G21

\section{Introduction}

Legal support of sustainable development and activity of banks in Ukraine, creation of proper competitive environment in the financial market, protection of legitimate interests of depositors and clients of banks, creation of favourable conditions for development of economy of Ukraine, and support of domestic commodity producer are the main purposes of normative regulation of banking activity (unnumbered paragraph 2, Art. 1 of Law of Ukraine On Banks and Banking No. 2121-III dated December 07, 2000 (hereinafter referred to as Law No. 2121-III)).

\footnotetext{
Corresponding author:

${ }^{1}$ Ivan Franko National University of Lviv, Ukraine.

E-mail: oleh.ilnytskyy@lnu.edu.ua

ORCID: https://orcid.org/0000-0001-7343-8810

${ }^{2}$ State University of Internal Affairs in Lviv, Ukraine.

E-mail: n.v.ilkiv@gmail.com

ORCID: https://orcid.org/0000-0002-3182-8391

${ }^{3}$ Ivan Franko National University of Lviv, Ukraine.

E-mail: tina1-83@ukr.net

ORCID: https://orcid.org/0000-0002-2619-2085
} 
The functioning of the deposit guarantee system for individuals is an important element in ensuring this goal. Through legal, institutional and organizationalfinancial mechanisms also, to ensure protection of the rights and legitimate interests of bank depositors, strengthen trust in the banking system of Ukraine, and ensure an effective procedure for removing insolvent banks from the bank liquidation market (part 2, Art. 1 of Law of Ukraine On the Deposit Guarantee System No. 4452-VI dated February 23, 2012 (hereinafter referred to as Law No. 4452-VI)).

The financial mechanism of accumulation of funds received from the sources specified in Art. 19 of Law No. 4452-VI with ensuring their further distribution and use in accordance with the regulatory purpose, mediated through the functions of the Deposit Guarantee Fund (DGF), is an organizational and financial guarantee to ensure the tasks of the Deposit Guarantee System. At the same time, crucial financial involvement of commercial banks in the development of the assets of the Deposit Guarantee Fund via payment of initial, regular and special charges (subparagraphs 1-3, part 1, Art. 19 of Law No. 4452-VI) simultaneously acts as the element of indicative regulation of banking operations by the National Bank of Ukraine. It establishes a directly proportional dependence between the defined empirical performance criteria of the relevant financial institution and the level of its mandatory payment in favour of the deposit guarantee system for individuals at the regulatory level.

Formally and actually, an important role is played by normatively defined qualitative indicators of banks' activity, along with quantitative ones for the general assessment of the generalized degree of risk of the Fund's participant. They account for $20 \%$ of the total score in the structure of the final assessment of the degree of risk of the activity. This further affects the formula economic calculation of the amount of fees. Thus, the established system ensures encouragement of good-faith performance of the Fund's participants (banks that have got a license for carrying out banking activity in Ukraine, of which currently there are 74 in Ukraine). At the same time, such significance requires uniform regulatory approaches to determining and applying respective qualitative indicators, since it leads to direct legal consequences for banking operations in Ukraine.

Building an effective deposit insurance system has long been of intersectoral scientific interest. It is of great importance for the stable functioning of the banking system and, consequently, for ensuring financial security. Significant commercial risk of banking results entails priority mass withdrawal of deposits, loss of confidence in the stability of financial institutions and policies, which further undermines the fundamentals of the monetary and credit market and accelerates its collapse in unfavourable periods of economic cycles, as experience shows.

One of the key roles in the financial safety net system is played by the deposit guarantee system. But the role of the deposit guarantee system in promoting financial stability is ambivalent (and may even become negative), which is mentioned in reference literature (Kane, 2016, 2007; Demirgüç-Kunt and Laeven, 2007). On the one hand, the insufficient level of coverage of deposits with guarantees increases the risk of panic among depositors during the crisis. As a result, there is a significant outflow of deposits. However, excessive protection through guarantees may reduce depositors' responsibility in the process of deposit placement as well as responsibility of the bank management. In particular, researchers stress that some financial security systems in general have shown the signs of unfair social and economic functional role during the latest crisis. So, some of them use the funds of citizens to save the wealth of owners of large financial institutions. Besides, different conditions of deposit guaranteeing for financial institutions competing in the same markets, if not adequately reflected in the price of deposits, will create conditions for regulatory arbitration and affect competition (Kane, 2016; Danylenko, 2017).

Back in the 2000s the International Monetary Fund and the World Bank jointly performed an applied analysis of the national deposit protection systems and their impact on the status of the banking system. The study embraced 61 countries, in which in total 898 observations were performed. Final results revealed a great diversity of the mechanisms used to protected depositors' interests. Bringing deposit protection system into conformity with general standards in such conditions becomes a rather complicated task (Dovnar, 2008), however some general approaches and positive practices to be accepted in the Ukrainian legal system have become the object of critical analysis and study (Andriievskaia, 2014; Buchko, 2016; Kurylo, Klochko, Timchenko, Gulyk, 2017; Adamyk, Skirka, 2017).

At the same time, the results of the conducted research contain a certain holistic generalization of the functioning of the deposit guarantee system in the economic, financial legal or criminal legal aspects. They do not disclose certain aspects of the practical application of the norms of its individual constituent elements, and leave these issues without proper theoretical justification. However, the relevance of the theoretical assessment of the quality of the relevant institutions testifies to the long-term functioning of the deposit guarantee system, especially in the global financial crisis of 2008-2009, as well as the political and socio-economic national crisis of 2014-2016.

Up till now critically few researches have been dedicated directly to specific steps and development of the 'roadmap' leading to the adjustment of the Ukrainian legal and financial system to the 
requirements of the regulatory documents of the European Union, that constitute the formal foundation for one of the important elements of the Economic and Monetary Union within the EU - (the European Deposit Insurance Scheme - EDIS) - Directive of the European Parliament and of the Council 2009/14/EC dated March 11, 2009, as well as Directive of the European Parliament and of the Council 2014/49/EC dated April 16, 2014. At the same time, detailed description of their content (Kovalenko, 2016; Hodak, 2017) leaves the mechanisms of implementation of specific requirements for the prospects of unification of the conditions of the bank system performance in the European space undisclosed. While establishment the amounts of payments to be made by the participants of the deposit insurance system on the basis of assessment of the risks of their operations (para. 16, Preamble, para. 3 (d), Art. 1 of Directive of the European Parliament and of the Council 2009/14/EC) and assignment of the authorities allowing to assess available risks of the system and take some preventive actions before their appearance to the institutions regulating the deposit guarantee system (para. 16, 36, 48, Art. 13 of Directive of the European Parliament and of the Council 2014/49/EC) constitute one of the vectors of the reform of the deposit guarantee system within EDIS.

The present research aims to establish the normative content of the qualitative indicators of bank performance in the application of sanctions by the National Bank of Ukraine and its significance for the development of a recurring charge to Deposit Guarantee Fund.

Materials of practical law enforcement became an occasion for detailed research of the declared problems. They noted the existence of significant inconsistencies between banks and the National Bank of Ukraine and the Deposit Guarantee Fund as banking regulators and supervisors on the content of quality indicators used in banking when determining the degree of risk for calculating recurring charge in the form of differential charge. This leads to the request of banking institutions for scientific opinions on the application of the relevant rules, taking into account the doctrinal interpretation of their content for further use as evidence to justify their position before the courts in the relevant disputes.

As the results of inspections performed by the Deposit Guarantee Fund in 2019, it was established that the Fund's participants, while calculating the amount of the recurring charge, made certain violations. These were the following: 1) unreliable estimation of the degree of risk by which the basic annual rate in the national and foreign currency was weighted; 2) wrong estimation of the score by quantitative and qualitative indicators; 3) unreliable determination and estimation of the base for accounting the recurring charge for deposits in the national and foreign currency, etc. The above in total led to submission of an unreliable report about recurring charge calculation to the Fund, underestimated amount of the recurring charge subject to payment to the Fund, wrong determination of the bank's risk degree, etc. On the basis of the results of inspections of banks for completeness of payments of charges to the Fund, underestimation of the amount of recurring charge paid by the banks to the Fund for the overall amount of $87.9 \mathrm{mln}$ UAH has been found, and due to this, a fine for incomplete payment of the recurring charge by the banks to the Fund in the amount of $11.7 \mathrm{mln} \mathrm{UAH}$ has been imposed. In general, violations in terms of completeness and timeliness of payment of charges to the Fund have been identified with 27 participants, and the share of this violation makes up $25 \%$ of all violations traced.

The authors of the present research have been involved in provision of respective opinions many times. The results constitute a commercial secret, but the general developed approaches to the assessment of the arguments of regulators of the market of banking services and its direct participants are provided in the text of the research as the outcomes of processing of the materials provided for verifying correctness of estimations.

The dialectical approach is the foundation of research, taking into account the specifics of the topic, purpose and task. Systemic method is applied to establish the content and assign qualitative indicators of bank performance for establishing their actual content in accordance with the regulation. On this basis, using a formal logical method, definitions of legal notions are formulated with due account of the financial and economic meaning as well as the established goal of legal regulation. Formal dogmatic method allows to make an analysis of the regulatory framework of the state, to identify functional capacity of the system of protection of the rights and interests of bank depositors, their technical and legal excellence.

Also, a number of other general scientific methods of research have been applied, in particular: analysis (to study systemic application of the notions), histo-rical legal (to study the establishment, change and development of the deposit guarantee system), comparative legal (to study the legislation determining specific principles of the functioning of the Deposit Guarantee System of natural persons in foreign states) etc.

\section{Characteristics of sources of financing the activities of the Deposit Guarantee Fund}

The bases of the financial redistributive mechanism of functioning of the deposit guarantee system are established by Articles 19 and 20 of Law No. 4452-VI. They identify the sources of funds of the DGF and the following legal areas of their use to achieve the objectives of this system. In the system of public finances of Ukraine 
Table 1

Development of financial resources of the Fund in 2019

\begin{tabular}{|l|c|}
\hline \multicolumn{1}{|c|}{ The source of development of the assets of the DGF } & mln UAH \\
\hline Recurring charge & $3,692.9$ \\
\hline Revenues from investment into state securities & 661.7 \\
\hline Revenues in the form of interest on the balance of money in the settlement accounts in the National Bank of Ukraine & 163.2 \\
\hline Repayment of internal governmental bonds & $2,805.4$ \\
\hline Money obtained from performance of measures envisaged by the regulation plan, including: & $4,885.3$ \\
\hline liquidation (repayment of creditor claims) & $4,406.7$ \\
\hline during interim administration (repayment of target loans) & 478.6 \\
\hline Other revenues, including: & 14.2 \\
\hline$\quad$ fines, penalties collected & 11.6 \\
\hline other revenues & 2.6 \\
\hline Total by all sources: & $12,222.7$ \\
\hline
\end{tabular}

Source: data of the Annual Report of the Deposit Guarantee System, 2019

there is an additional guarantee state extra-budgetary fund, which acts as a source of ensuring the legitimate property interests of depositors. This corresponds to the chosen American model of bank deposit insurance system.

In spite of the public nature of the Fund's operations, as far as ensuring administration is concerned, the sources of development determined by Art. 19 of Law No. 4452-VI testify to a high degree of financial selfgovernance of the system.

It has been determined that the core sources of the assets of the Deposit Guarantee Fund in 2019 (over $30 \%$ of the sources of financial resources development) include recurring charges from the Fund's participants (para. 2, part 1, Art. 19 of Law No. 4452-VI). They are paid in the fixed amount under unnumbered paragraph 1, part 1, Art. 22 of Law No. 4452-VI, or under the regulatory legal act of the Deposit Guarantee Fund in the form of differential charges. This is calculated by weighing of the basic annual charge rate by the degree of risk of the participant's operations (paragraph 4, part 1, Art. 22 of Law No. 4452-VI).

\section{Fundamentals of the risk assessment methodology of the bank-member of the Deposit Guarantee Fund}

The basics of the methodology of estimating the amount of recurring charges in the form of differential charges are set in the Regulation on the Procedure of Estimation, Accounting and Payment of Charges to the Deposit Guarantee Fund, approved by Decision of the Executive Directorate of the Deposit Guarantee Fund No. 1 dated July 02, 2012 (registered with the Ministry of Justice of Ukraine on February 27, 2012, No. 1273/21585) (hereinafter referred to as Regulation No. 1), as well as the Algorithm of Estimation and Threshold Values of Quantitative Indicators, Score by Qualitative and Quantitative Indicators for the Determination of the Degree of the Bank's Risk in the Estimation of the Recurring Charge in the Form of
Differential Charge to the Deposit Guarantee Fund, passed to ensure its enforcement, approved by Decision of the Executive Directorate of the Deposit Guarantee Fund No. 5513 dated December 26, 2017.

The degree of risk is a numerical indicator of the Fund's participant, under unnumbered paragraph 2, part 1, section IV of Regulation No. 1. The degree of risk is determined with due account of the bank category, the degree of risk and the overall score calculated in accordance with the figures determined by the Fund, that characterize the indicators. The list of indicators, component indicators used for their calculation is presented in Tables 1, 2 of Annex 4 to Regulation No. 1.

The indicators have been established and united by their content into two categories - quantitative and qualitative. Table 1, Annex 4 of Regulation No. 1 contains the list and ranging of quantitative indicators characterizing the level of capital (indicator: $\mathrm{K} 1, \mathrm{~K} 2$ ); quality of assets (indicator: ЯA1, ЯA2, ЯA3); liquidity level (indicator: $\Lambda 1, \Lambda 2, \Lambda 3$ ); efficiency of performance (indicator: E1, E2, E3); liabilities management quality (indicator: $\Pi 1, \Pi 2$ ).

Qualitative indicators, instead, characterize the banks' compliance with the legislative requirements, including regulatory legal acts of the National Bank of Ukraine, the Fund, compliance with the requirements and obligations set by them. In total they determine the degree of formal good faith of the banking institution by the fixed indicators-criteria (Table 2).

Among other things, para. 1 of Table 2 'The list of qualitative indicators' (20\% of the overall score)' of Annex No. 4 (para. 1, chapter IV) contains the following qualitative indicator. It is taken into consideration in the estimation of recurring charges of the Fund's participants in the form of differential charges - 'over the reporting quarter the National Bank of Ukraine has not applied any means of influence to the bank, but for a written warning and a fine for submission of distorted statements under the regulatory legal act on application of means of influence.' The above regulatory formulation 
Table 2

The list of qualitative indicators for the determination of the degree of risk in bank operations

\begin{tabular}{|c|l|}
\hline № & \multicolumn{1}{|c|}{ List of qualitative indicators } \\
\hline 1 & $\begin{array}{l}\text { Over the reporting quarter the National Bank of Ukraine has not applied any means of influence to the bank, but for a written warning } \\
\text { and a fine for submission of distorted statements under the regulatory legal act on application of means of influence. }\end{array}$ \\
\hline 3 & $\begin{array}{l}\text { The National Bank of Ukraine does not apply any special regime of controlling performance to the bank and no supervisor has been } \\
\text { appointed for the bank due to available financial problems in its operations. }\end{array}$ \\
\hline 4 & $\begin{array}{l}\text { The Bank ensures timely and complete performance of its financial commitments to the National Bank of Ukraine. } \\
\text { transactions with the persons related to the bank into conformity with the requirements of the National Bank of Ukraine and/or } \\
\text { compliance with the requirements of the regulatory legal acts of the National Bank of Ukraine for the sake of avoiding or overcoming } \\
\text { unfavourable consequences that may pose a threat to the security of money entrusted to this bank or bring harm to the due process of } \\
\text { banking operations. }\end{array}$ \\
\hline 5 & $\begin{array}{l}\text { No administrative and economic sanctions have been applied to the bank for violation of the legislative requirements related to the } \\
\text { deposit guarantee system. }\end{array}$ \\
\hline
\end{tabular}

Source: Annex 4 to Regulation on the Procedure of Estimation, Accounting and Payment of Charges to the Deposit Guarantee Fund, approved by Decision of the Executive Directorate of the Deposit Guarantee Fund No. 1 dated July 02. 2012 (registered with the Ministry of Justice of Ukraine on February 27, 2012 under No. 1273/21585)

constitutes one of the sources of disputable situations between the Deposit Guarantee Fund and banks participating in the deposit guarantee system.

\section{Legal nature of measures of influence of the National Bank of Ukraine}

"Measures of influence" are regulated by Article 73 of Law No. 2121-III. They are sanctions of administrative or financial nature, applicable by the National Bank of Ukraine within the administrative regulation of banking. Means of influence are applied by the National Bank of Ukraine in case banks or other entities, which may be subject to inspections conducted by the National Bank of Ukraine under Law No. 2121-III, violate banking, currency legislation, legislation in the field of prevention and counteraction of legalization (laundering) of income obtained by criminal means, or financing of terrorism and proliferation of weapons of mass destruction, regulatory legal acts of the National Bank of Ukraine, its requirements set under Art. 66 of Law No. 2121-III, or in case they conduct any risky operations that pose a threat to the interests of depositors or other bank creditors, in case foreign states or interstate associations or international organizations apply sanctions against banks or holders of a significant share of the bank, and that constitutes a threat to the interests of depositors or other bank creditors and/or stability of the banking system, in proportion to the committed violation or the degree of such threat. The above list of means of influence includes written warning (para. 1, part 1, Art. 73 of Law No. 2121-III) and fine imposition (para. 9, part 1, Art. 73 of Law No. 2121-III).

The procedure of application of the means of influence set by Article 73 of Law is determined by the regulatory acts of the National Bank of Ukraine. Currently, such act is the Regulation on the Application of Means of Influence by the National Bank of Ukraine, approved by Resolution of the Management Board of the National Bank of Ukraine No. 346 dated August 17, 2012 (registered with the Ministry of Justice of Ukraine on September 17, 2012 under No. 1590/21902) (hereinafter referred to as Regulation No. 346).

Regulation No. 346 determines the procedure for selecting means of influence to be applied to banks, specifies the norm of para. 1, Art. 73 of Law 2121-III. These means shall be adequate to specific violations that have been committed. Selection of adequate means of influence shall be performed with due account of the nature of the violations committed by the bank; the reasons that have caused appearance of the violations traced; the overall financial status of the bank; the amount of possible negative consequences for creditors and depositors; information of the Deposit Guarantee Fund on violation of the requirements set by the Law of Ukraine On the Deposit Guarantee System by banks, the results of bank inspection conducted by the Fund (para. 3.2, section 3, chapter I). The obligatory element of the decision on application of means of influence is quantitative, qualitative assessments and opinions of the National Bank of Ukraine, including conclusions about availability of signs of the bank's risky operations posing a threat to the interests of depositors or other bank creditors as well as substantiation of the adequacy of application of a specific means of influence on the basis of established circumstances (facts) (unnumbered paragraph 3, part 3, Art. 73 of Law No. 2121-III).

Thus, the Board of the National Bank of Ukraine or the Committee on Supervision and Regulation of Banking, Oversight of Payment Systems applies measures of influence and conducts the necessary qualification on the severity and danger of the established violation, compares it, according to the criteria, with the adequacy of selected measures impact. 


\section{The impact of the applied measures on the assessment of the degree of risk of banks in Ukraine}

The study of the system of measures of influence shows that a written warning on its content is a requirement for the bank to eliminate violations of banking, currency legislation, legislation on financial monitoring, regulations of the National Bank of Ukraine and/or take measures to prevent such violations in further activities (para. 1.1, 1.3 of Chapter 1 of Section II of Regulation No. 346). Thus, by its legal consequences written warning contains the minimum scope of actual punitive element among the listed means of influence and does not cause any significant interference into the activity of the financial institution in relation to which the written warning is made. Written warning is of a universal nature of application. The openness of the list of grounds for its application is evidence of this (subparagraph ' 3 ', para. 1.3, section 1, chapter II of Regulation No. 346 'other violations'). Due to this, written warning should be considered the smallest means of influence to be applied for any committed violation on the basis of the opinion of the National Bank of Ukraine or the Committee on Supervision and Regulation of Bank Performance, Oversight of Payment Systems on the sufficiency of statement and raising of the requirement to eliminate the violation to counteract its negative consequences for the sake of protecting the interests of depositors or other bank creditors, functioning of the banking system.

It is logical that the nature of the written warning as a means of influence, its application in case of violation, indicates a competent official conclusion of the national banking regulator to ensure a low level of risk in the activity. This does not require significant intervention and additional warnings from the state.

Imposition of fine as a means of influence is applied in cases envisaged by section 9 of chapter II of Regulation No. 346, including for violation of the requirements of the regulatory legal act of the National Bank of Ukraine that regulates the procedure of filling out and submission of statistical reporting to the National Bank, viz.: for non-submission/untimely submission of statistical reporting or submission of unreliable statistical reporting (unnumbered paragraph 5, para. 9.1, section 9, chapter II of Regulation No. 346). Also, para. 9.8, section 9, chapter II of Regulation No. 346, determines the differentiation of the penalty, and names its grounds - significant or insignificant errors in statistical reporting as such grounds, which fact testifies to the difference in the approaches to the need of taking into account the adequacy of applied means of influence even within the framework of implementation of one of them. They depend on the consequences of the violation.
Reporting deficiencies do not significantly affect the actual operations of the financial institution. As a result, exceptions have been established for the submission of distorted reporting for the calculation of the regular fee in the form of a differentiated fee for the application of a measure of influence in the form of a fine. They are a formal violation that can have varying degrees of materiality as the violation itself, and different causes (including error). At the same time, establishment of unreliable data in reports as the result of violations in actual performance will lead to application of other means of influence for the respective violations.

In these conditions, in their logical interrelation, non-compliance with the provision of the qualitative indicator concerning absence of means of influence applied to the bank over the reporting quarter testifies to availability of an empirical confirmation of the growing degree of risk in the operations of the Fund's participant. The increase in the size of the recurring charge in the form of a differentiated charge as compared to the participants whose activities meet the above indicators is proportionally determined.

The European Court of Human Rights analyses the observance of the guarantees of the Convention for the Protection of Human Rights and Fundamental Freedoms in the Activities of Public Authorities and keeps stressing the special importance of the principle of "good governance". It presupposes that when it is all about the issue of general interest, in particular, if the case affects such basic human rights as proprietary rights, state authorities must act in a timely and most consistent manner (see judgments in the cases Beyeler v. Italy [GC], application №. № 33202/96, p. 120; Öneryıldiz v. Turkey [GC], application No. 48939/99, p. 128; Magadat.com S.r.l. v. Moldova, application No. 21151/04, p. 72, dated April 08, 2008, and Moskal v. Poland, application No. 10373/05, p. 51, dated September 15, 2009). In particular, state authorities have the duty to introduce internal procedures that will increase transparency and quality of their actions, minimize the risk of error occurrence (see, for example, judgments in the cases Lelas v. Croatia, application No. 55555/08, p. 74, dated May 20, 2010, and Toscuta and Others v. Romania, application No. 36900/03, p. 37, dated November 25, 2008) and will contribute to legal certainty in civil law relations connected with proprietary interests (see above judgments in cases Önerylldiz v. Turkey [GC], application No. 48939/99, p. 128; Beyeler v. Italy [GC], application No. 33202/96, p. 119) (p. 70 of the judgment of the European Court of Human Rights in the case Rysovskyi v. Ukraine, application No. 29979/04 dated October 20, 2011).

Being guided by the above principle, the use of the notion '...for submission of distorted reporting...', in relation to which there is no normative counterpart in Regulation No. 346, in para. 1 of Table 2 'The list of qualitative indicators ( $20 \%$ of the overall score)' 
of Annex No. 4 (para. 1, chapter IV) to Regulation No. 1 constitutes an independent ground for acknowledging illegitimacy of such definition. The nature of the means of influence as sanctions and such a textual discrepancy between the grounds for their application and the further consequences for the impact on the legal status of a person in the field of property rights should always be interpreted in favour of the person.

However, para. 5 of Table 2 'The list of qualitative indicators ( $20 \%$ of the overall score)' of Annex No. 4 (para. 1, chapter IV) to Regulation No. 1, makes determination of the degree of risk in activity depends on the application of administrative and economic sanctions for the violation of the legislative requirements set for the deposit guarantee system over the reporting period to the bank.

According to Art. 33 of Law No. 4452-VI, if the bank violates the legislation on the Deposit Guarantee System, the Fund shall apply administrative and economic sanctions to the bank in the form of a written warning, or a fine, or a decree on elimination of violations of the legislation on the Deposit Guarantee System in proportion to the committed violation.

In 2019, the Fund imposed sanctions on banks for the following violations: 1) non-submission of the data to the Fund by the bank in case submission of such data was required by the law and/or regulatory legal acts; 2) untimely submission of the data to the Fund by the bank in case submission of such data was required by the law and/or regulatory legal acts of the Fund; 3) submission of unreliable data to the Fund by the bank in case submission of such data was required by the law and/or regulatory legal acts of the Fund; 4) violation of the procedure of depositor data base maintenance by the bank; 5) non-performance of decisions and/ or regulatory legal acts of the Fund or decrees on the elimination of violations of the legislative requirements on guaranteeing of deposits of natural persons by the bank; 6) untimely performance of decisions and/ or regulatory legal acts of the Fund or decrees on the elimination of violations of the legislative requirements on guaranteeing of deposits of natural persons by the bank. Respectively, the official authorized to hear cases, as of January 01, 2020, passed 128 decisions of which: 48 were warnings about taking steps to prevent violation of legislation on the deposit guarantee system in further activity; 75 were decrees about elimination of violations of the legislation on the deposit guarantee system; 5 were resolutions on the closure of the case on legal violations in the field of guaranteeing of deposits of natural persons.

Unlike para. 1 of Table 2 'The list of qualitative indicators (20\% of the overall score)' of Annex No. 4 (para. 1, chapter IV) to Regulation No. 1, para. 5 does not contain any warnings concerning any exceptions for estimating the recurring charge in the form of differential charge depending on the type of sanction or the violation for which it is applied.

Taking into account the above conclusions concerning legal significance of warning within sanctions for violations in the field of banking as well as for ensuring actual differentiation depending on the stated degree of risk in the operations of a controlled banking institution, we consider that such single-option wording testifies to the fiscal goal of controlled forms of the Fund's operations. Thus, under the Plan of Holding Inspections of the Participants of the Deposit Guarantee Fund for 2019, approved by decision of the Executive Directorate of the Fund No. 2943 dated November 01, 2018, in 2019 the Fund's staff performed all in all 68 inspections of banks. According to the results of the inspection, no violations were found in only 10 banks (15\%). At that time, violations of different severity and for various reasons (including technical) were allowed in $85 \%$ of inspected institutions ( 58 banks). However, in the current conditions of legal regulation there is no opportunity to differentiate them as necessary by qualitative indicators of the degree of risk in their operations.

\section{Conclusion}

Taking into account legal importance of written warning of the National Bank of Ukraine as a means of influence, judging by the systemic, logical and semantic interpretation of the prescription of para. 1 of Table 2 'The list of qualitative indicators (20\% of the overall score)' of Annex No. 4 (para. 1, chapter IV) to the Regulation on the Procedure of Estimation, Accounting and Payment of Charges to the Deposit Guarantee Fund, approved by decision of the Executive Directorate of the Deposit Guarantee Fund No. 1 dated July 02, 2012 (registered with the Ministry of Justice of Ukraine on February 27, 2012 under No. 1273/21585) the notion '...for submission of distorted reporting...' is not related to specification of cases of exception application as far as means of influence in the form of written warning are concerned, and is related to fine imposition only.

Exceptions in the form of written warning and find for submission of distorted reporting, applied by the National Bank of Ukraine, is caused by low level of severity of the respective violations of law and objective conditions under which they are committed and under which respective means of influence can be applied, as well as establishment in the law enforcement decision of the absence or low degree of threat to the protection of the interests of depositors or other bank creditors or the functioning of the banking system. This allows you to select these means of influence as adequate. This does not indicate to any deviation from qualitative indicators and an increase in the degree of risk in the bank's activities. 
At the same time, the provision of para. 5 of Table 2 "List of quality indicators (20\% of the total score)" of Annex No.4 (para. 1 of section IV) to the Regulation on the procedure for calculating, accruing and paying fees to the Deposit Guarantee Fund approved by the Executive Board DGF dated July 2, 2012 № 1 (registered in the Ministry of Justice of Ukraine on February 27, 2012 under № 1273/21585) on the legal significance of administrative and economic sanctions for violation of the legislation on the deposit guarantee system for individuals is unalterable. It does not take into account the difference in the legal nature of such sanctions, the grounds (violations) of their application, which complicates the differentiation of the participation of banks in the Fund depending on the degree of risk of their activities.

\section{References:}

Buchko, I. (2016). Osnovni zasady funktsionuvannia Fondu harantuvannia vkladiv fizychnykh osib u sysytemi bankivskoi bezpeky [Basic principles of functioning of the Deposit Guarantee Fund in the banking security system]. Ekonomika ta suspilstvo [Economy and society], vol. 5, pp. 325-329. (in Ukrainian)

Garantii zashchity prav potrebitelei bankovskikh uslug v stranakh Evrosoiuza [Guarantees of protection of the rights of consumers of banking services in the countries of the European Union]. Available at: http://law-clinic.net/ article/200/2083 (in Russian)

Kurylo, M., Klochko, A., Timchenko, G., \& Gulyk, A. (2017). Banking in Ukraine as an object of criminal and legal protection. Banks and Bank Systems, vol. 12(4), pp. 114-120. doi: 10.21511/bbs.12(4).2017.11

Skarka, A., \& Adamyk, B. (2017). Problematyka finansovoi diialnosti Fondu harantuvannia vkladiv fizychnykh osib [Problems of financial activity of the Deposit Guarantee Fund]. Hlobalni ta natsionalni problemy ekonomiky [Global and national economic problems], vol. 19, pp. 462-468. (in Ukrainian)

Skarka, A., \& Adamyk, B. (2016). Dzherela formuvannia koshtiv Fondu harantuvannia vkladiv fizychnykh osib ta analiz yih vykorystannia [Sources of formation of funds of the Deposit Guarantee Fund and analysis of their use]. Ukrainian Journal of Applied Economics, T. 1, 3, pp. 5-20. (in Ukrainian)

Andrievskaia, I. (2014). Prozrachnost bankovskoi sistemy i konkurentciia: mezhstranovoi analiz [Transparency of the banking system and competition: cross-country analysis]. Voprosy ekonomiki [Economic issues], vol. 9, pp. 96-112. (in Russian)

Fond harantuvannia vkladiv fizychnykh osib. Richnyi zvit za 2019 rik [Deposit Guarantee Fund. Annual report for 2019] (2019). Available at: https://www.fg.gov.ua/storage/editor/files/richniy-zvit-fondu-2019.pdf (in Ukrainian)

Law of Ukraine On Banks and Banking No. 2121-III dated December 07, 2000. Available at: http://zakon2.rada.gov.ua/laws/show/2121-14 (in Ukrainian)

Law of Ukraine On the Deposit Guarantee System No. 4452-VI dated February 23, 2012. Available at: http://zakon2.rada.gov.ua/laws/show/4452-6 (in Ukrainian)

Danylenko, A. (2017). Evolving Ukraine's Deposit Guarantee System Towards Global Standards: A Macroprudential Perspective. Visnyk of the National Bank of Ukraine, vol. 242, pp. 14-27. doi: 10.26531/vnbu2017.242.030

Demirgüç-Kunt, A., Kane, E., \& Laeven, L. (2007). Determinants of deposit-insurance adoption and design. Working Paper, 12862, NBER. doi: 10.3386/w12862

Folkerts-Landau D., \& Lindgren C.-J. (1998). Toward a Framework for Financial Stability. World Economic and Financial Surveys. International Monetary Fund. doi: 10.5089/9781557757067.083

Kane, E. J. (2016). Financial safety nets: the good, the bad and the ugly. Boston College. Available at: https://www2.bc.edu/edward-kane/Financial\%20Safety\%20Nets\%20GoodBadUgly.pdf

Dovnar, Iu. (2008). Problema zashchiti vkladov v prave Evropeiskogo Soiuza [The problem of protection of bank deposits in the law of the European Union]. Pravo i demokratiia [Law and Democracy], vol. 19, p. 189. (in Russian) Amending Directive 94/19/EC on deposit guarantee schemes as regards the coverage level and the payout delay: Directive 2009/14/EC of the European Parliament and of the Council of 11.03.2009. Official journal of European Union, 2009. L 68, 13.3.2009. P. 0003-0007.

On deposit guarantee schemes: Directive 2014/49/EU of the European Parliament and of the Council of 16.04.2014. Official journal of European Union, 2014. L 173, 12.6.2014. P. 0149-0178.

Hodak, Ye. (2017). Administrative and legal status of the Deposit guarantee fund. Ternopil.

Regulation on the Procedure of Estimation, Accounting and Payment of Charges to the Deposit Guarantee Fund, approved by Decision of the Executive Directorate of the Deposit Guarantee Fund No. 1 dated July 02, 2012 (registered with the Ministry of Justice of Ukraine on February 27, 2012 under No. 1273/21585). Available at: https://zakon.rada.gov.ua/laws/show/z1273-12\#Text (in Ukrainian)

Regulation on the Application of Means of Influence by the National Bank of Ukraine, approved by Resolution of the Management Board of the National Bank of Ukraine No. 346 dated August 17, 2012 (registered with the Ministry of Justice of Ukraine on September 17, 2012 under No. 1590/21902). Available at: https://zakon.rada.gov.ua/laws/show/z1590-12\#Text (in Ukrainian)

Case of Rysovskyi v. Ukraine (Application no. 29979/04) 20/10/2011. European Court of Human Rights. Available at: http://hudoc.echr.coe.int/fre?i=001-107088

Kovalenko, A. (2016). Public and legal regulation of banking activity in Ukraine in terms of European integration. Kyiv. 